\title{
The Impact of Deceptive Advertising on Customer Loyalty: A case of Telecommunication Industry in Karachi, Pakistan
}

\author{
Saira Iqbal (Corresponding author) \\ Karachi University Business School, University of Karachi, Pakistan \\ E-mail: saira.khan2500@gmail.com \\ Dr. Danish Ahmed Siddiqui \\ Associate Professor \\ Karachi University Business School, University of Karachi, Pakistan \\ E-mail: Daanish79@hotmail.com
}

Received: April 3, 2019

Accepted: April 14, 2019

Published: April 15, 2019

doi:10.5296/ijim.v4i1.14607

URL: https://doi.org/10.5296/ijim.v4i1.14607

\begin{abstract}
This study examined the impact of Deceptive Advertising on Customer Loyalty in the telecommunication industry of Karachi, Pakistan. This research was quantitative in nature. The sample size was 250; questionnaires were distributed electronically and manually. Exploratory Factor Analysis (EFA) was used to analyze the data with the help of SPSS. Confirmatory Factor Analysis (CFA) and Structural Equation Modeling (SEM) using AMOS, conducted to ensure the model and testing the hypothesis. The outcome of the present study verifies that word of mouth has a strong significant influence on customer loyalty. Hence customer satisfaction and customer trust are causing word of mouth in a positive and significant way. So it shows that there is a positive and strongly significant influence of customer satisfaction and trust on customer loyalty with the mediation of word of mouth. On the other hand, deceptive ads are causing word of mouth in a negative way. Hence it is concluded that deceptive ads have a negative influence on customer loyalty with the mediation of word of mouth. This study suggested that in order to increase customer loyalty and build a long-term relationship with the customer's telecom companies should focus on accurate information and rendering the level of competitive services to their customers.
\end{abstract}

Keywords: Deceptive advertising, Customer satisfaction, Customer loyalty, Word of mouth, Customer trust 


\section{Introduction}

\subsection{Background}

In today's competitive business environment no business can become a market leader unless they spent millions of dollars in promotional purposes. The key purpose of advertisers is to achieve valuable consumers by influencing their thoughts, knowledge and buying behavior.

There are different mindfulness methods of communication for example, occasions, individual selling, public relations, direct marketing, word of mouth marketing, and advertising (Fill, 1999; Kotler, 2010). Individual selling is also known as face to face selling where one individual (sales person) attempts to persuade the client in acquiring an item (Definition of 'Personal Selling'). Public relations (PR) are the method individuals and companies communicate with the media and public. A PR expert communicates with the target audience indirectly or directly through the media with an aim to maintain a positive image and generate a strong connection with the audience (PAHWA, 2018). Direct marketing is the process of selling the product or service directly to the people e.g.by telephone selling or by mail order (Outreach). Presently multi day's customer faces the test of making do with these methods of showcasing correspondence. Amongst all the above modes of communication, advertising has the main impact on viewers mind and as a strategy, it is the most important part of any business entity which is used to generate awareness about product or service. The term advertising is derived from the Latin word 'advertere' means to turn the attention. The term advertising is gotten from the Latin word 'advertere' signifies to turn the consideration. The word 'advertising' first develop around 1665 A.D. All aspects of advertising attempt to turns the consideration of the pursuers or the audience towards the product. Advertising is the mean of advising just as affecting the overall population to purchase a product or service.

A product or service is promoted to make mindfulness in the brains of potential purchasers through a different publicizing medium, for example, magazine, radio, TV, bulletins, web publicizing, paper, and so forth. Promoting typically gives data about the publicizing firm, its service characteristics, its product and the spot of accessibility (Singh, 1996).

An advertisement turns into misleading or false when untruthful or deceptive statements are used in the ads to attract the customer towards the product or services. (M., 1975) has identified deceptive advertising in 1975. As deceptive advertising begins when a firm or a company support its product or services with the help of misleading, untrue of confusing statements. The tricks e.g. using of Photoshop to change the appearance of the products are used by the advertiser in order to deceive the customers and make their product look a lot diverse than the reality. So, this kind of advertisement is unsafe for consumers as they are intentionally mislead by the misrepresentation of quality, characteristics or the nature of the product or service offered by various firms (Skool). This incorrect statement of the product leads the customers to make poor decisions in result to which the customer end up wasting precious money on something which won't meet their needs or resolve their problems (Taruna, September 2016). 
According to (Lodhi, 2015) deceptive advertising is the use of misdirecting, false and wrong publicizing of an item which may adversely influence purchaser's faithfulness, duplicity can be affirmed when a buyer exclusively consume or experience the item or service. On the off chance that buyers are not being educated about the total data or being uncovered pictures that restrict the genuine characteristics of a product or service, they are unsure to create the best choices for themselves (Ray, 2018).

One's any company engages in misleading advertising it isn't a trustworthy company more as both the new and existing customers may suffer deceive and switch to another company product or services. The business may likewise get an awful status as a misleading association, which implies declining business later on. Besides, in rising markets like Pakistan, it is increasingly basic to decide if the components, for example, customer satisfaction, word of mouth, and trust additionally influencing customer Loyalty because of the continual entry of inventive players in potential organizations. That is the reason organizations make superior associations with their faithful customers, as they purchase their products and services over and over (Waheed Akhter, 2011) and however, this can be done when once trust is developed.

According to (Owais Hassan, 2014) the Pakistani customer is no different from the customers in another marketplace in the world. Deceptive advertising is now also illegal in many other countries (FTC Guides Against Deceptive Pricing, 2012). The United States of America was the first to execute policies and rules about deceptive advertising. The United States Supreme Court has lined that misleading or false advertising is not sheltered under the first adjustment (Demaine, 2010). In this way, some of the agencies have been designed and created to discourage service providers and manufacturers to use deceptive advertising in order to protect the customers. According to the European Commission's instruction, false advertising is any advertising which in any mean, counting in its presentation, is proficient of misleading the person to whom it is concentrated, misrepresented their behavior and as a result, destruction the interest of the customers (Official Journal of the European Union, 2005). As from China to India to the United Kingdom, misleading advertising is banned. Not merely deception is banned but it is also carefully be regulated. Most countries entail advertorials ads that are obtainable as editorial, to be obviously marked as advertisements. The charge of breaking these laws can be steeped both in humanitarian and financial consequences (Wakeman).

In order to enter into a specific market it is exceptionally noteworthy to initially get a knowledge about the taste, clients' needs, culture and socioeconomics of that market, not exclusively to propose a product yet in addition to develop its one of a kind methodologies.

Since telecom administrators present services for all market fragments, they use differing advancement and promoting systems for every one of their services. Being the component of the most focused business every operator of telecom industry of Pakistan expects to bring some interesting and out of the case promotion techniques so as to satisfy their customers. As the service scope of every operator is pretty much like what can have any kind of effect is the special and promoting methodologies every operator uses to make their customer base and 
image.

They are doing advertising through television, internet, newspaper, banners, sign boards, FM radio, and mobile vans. Among all Television, the advertisement is the most essential source for effective branding of Telecom Industry. They spend a lot of the money to run their TV's on numerous channels, while TV channels differ according to the market standing and channel (TRP) rating. As indicated by the MEDIA BANK PAKISTAN articulation of 2015, telecom industry acquired hold of $20 \%$ of shares of complete minutes of promoting and positioned second in the top classification list with, Mobilink, Ufone, and Telenor being the most dynamic telecom players. Web and Social media likewise have turned into the most imperative medium to make a superior position in the market and make the brand known in the market. The Telecom operator of Pakistan is among the top brands on the web. Every operator has an exceptional site as well as truly powerful on every single social medium stages. Not only on Facebook but as well as Twitter is lead by the telecom sector (Rizwana, 2016).

\subsection{Problem Statement}

Advertising assumes a huge job in affecting customer behavior so as to buy a product or service. With the passage of time customers are badly affected by different marketing activities and deceptive advertising. Moreover, false advertising is a very responsive issue because most customers are unable to understand and interpret advertisements. Some time's the advertisers over exaggerate the product's benefits and advertise them in such a thoughtful way, therefore customers should be very well aware of their purchase decision. After explaining the deceptive advertising in detail, the research study will demonstrate how customers can respond after getting deception in advertisements for the product or service they purchased.

Telecommunication industry is like the backbone for every country in the era of communication and speediness industry in the current business environment. Pakistan Telecommunication Business Limited has a very wide telecommunication network crosswise the country covering all the main areas. Telecommunications in Pakistan explains the large environment for the growing mobile telecommunications, internet and telephone markets in Pakistan. According to (Mittal, 2017) Pakistan's telecom sector appears as one of the fastest rising sectors across Asia and in 2008 it was the third -fastest rising sector in the world. The growth has continued unconstrained till date and as of 2017 January, out of the population of almost 200 million 16 percent are active on social media, 23 percent are active internet users, and 72 percent are mobile subscribers. The telecom infrastructure in Pakistan is improving significantly with domestic and foreign investments in mobile networks and in the fixed-line (WILSON, 2009). According to (Farooq, 2018) Pakistan telecom sector revenues through the first two-quarters FY(Financial year) 2017-18 touched Rs. 235.5 billion, discovered the Economic Survey of the (2017-18).

Pakistan has been a nation with a monopolistic market in the media transmission area yet from the previous two decades, both worldwide and national member have altered its elements for working business. As the greater populace volume of the nation was a tempting 
element for telecom organizations to enter the market (Mehnaz, 2016). With the progression of time, the cell phone administrators have showed up in each territory of the world (Shaista Kamal, 2015). The event of numerous operators in the marketplace offered an approach to focused valuing and hard challenge. Given the solid challenge, organizations turned to tricky promotions so as to exploit feelings, take benefit from low proficiency of the customers and just as control customer mind. The researcher also explained that the transmission of misleading information in respect to telecommunication services and products may take any form, it may be through television advertisements, brochures, billboards and banners, print media, advertisement on the internet, short message services (SMS) offers. Telecom companies in Pakistan have somehow engaged to deliver overstated statement to influence the consumers due to which customers lost their money and get mental misery. As (Jeeva, 2016) said that deceptive ads influence purchaser's decisions concerning what they buy. Such advertisements generate a belief about the quality of the product and services which is not true and also create the wrong impression about the product in the result to which customer preference will be distorted. The bundles offered, for example, SMS charges, availability charges, call rates, post, and prepaid associations are continually taking up additional charges for simply buying in, which the customer doesn't understand and have very little familiarity with this charged data, which at last disturbs buyers which pattern the customers for brand exchanging (Hasan, 2011).

\subsection{Research Gap}

(Mohammad Noorizzuddin bin Nooh, 2014) has explored the effect of unethical advertising criteria that impact to the next creation. The study converse that misleading and inappropriate advertising makes negative belief in the psyche of people particularly children or adults in Malaysia. (Maicibi, 2013) have featured that misleading ads create wrongly utilization of customer loyalty in the association in America. The research observes that organization should generate a specific cost for the falsification and fraud in advertising in order to keep the organization healthy and competitive. Further to it (Jeeva, 2016) have highlighted the impact of misleading advertisement in Coonoor, India and explored that misleading advertisement has an unfavorable effect on consumer interests.

In spite of the fact that there are past examinations on the issue of deceptive advertising with reference to telecommunication area in Pakistan (Hasan, 2011), (Fayaz, 2015) and (Shaista Kamal Khan, 2015), be that as it may, these investigations for the most part center around characterizing the deceptive advertising and to some degree mirror on its impact on the customer loyalty. As (Shaista Kamal Khan, 2015) seen that consumer behavior is influenced by, budgetary or emotional misfortune, misdirecting and erroneous understanding case that patterns to influence trust, consumer loyalty, and brand frame of mind. (Hasan, 2011) examined that deceptive or misleading elements are present in the ads which may affect customer loyalty. (Fayaz, 2015) likewise directed an investigation and saw that deceptive advertising rehearses occur in cell phone advertisement which influences customer loyalty. While none of them directly spotted out the effect and relationship between the deceptive advertising and customer loyalty. Moreover, these studies including studies done on Pakistan didn't emphasize on how deceptive advertisement interplays with trust and customers 
satisfaction to effect loyalty, moreover, how words of mouth mediate this phenomenon. Along these lines, clarifying the impact of deceptive advertising on loyalty within the sight of trust and satisfaction through word of mouth is still under research particularly on account of creating a nation like Pakistan. Subsequently, there is a justifiable research gap to contemplate the connection between customer loyalty and deceptive advertising under the mediation of word of mouth. (Hasan, 2011) and (Jahanzeb, 2015) proved that deception in ads affecting customer behavior. But they mostly focus on describing deceptive advertising and to some degree imitate on its impact on customer loyalty. The originality of this paper is also to study the relationship between customer loyalty and deceptive advertising under the mediation of word of mouth. The completion of this research provides an essential benefit to the customers by informing them about the false or wrong advertisements of a product or service which may negatively affect their loyalty.

This study also gives benefit to marketers in order to make them assure that now a day's customers are more knowledgeable because of the technological era. So, it's very essential for advertisers to provide truthful statements about the product or service they advertised.

\subsection{Research Objectives}

The scope of the research is to highlight the study on deceptive advertising that helps to determine its effect on customer loyalty and also to know the increasing demand of telecommunication industry in Pakistan. Most of the time, customer get disappointed from advertising due to inappropriate execution and non-fulfillment, of particular commitment, the study will help consumers to get aware of the false advertisements and its effect on their loyalty. However, the study is conducted in Karachi city from people of diverse age group. Furthermore, this study has examined how the customer reacts after deception in an advertisement.

The objectives of this research are:

1) To recognize the influence of deceptive ads on customer loyalty with the mediation of word of mouth.

2) To recognize the influence of customer satisfaction on customer loyalty with the mediation of word of mouth

3) To recognize the impact of customer trust on customer loyalty with the mediation of word of mouth.

4) To examine the influence of word of mouth on customer trust.

5) To recognize the influence of word of mouth on deceptive ads.

6) To identify the relationship between customer trust, customer loyalty and deceptive advertisement.

7) To examine the influence of word-of-mouth on customer satisfaction. 


\subsection{Research Questions}

This research attends to get answers to the following questions:

- To what degree deceptive advertising effect on customer loyalty?

- To what extent marketers make efforts to stimulate customer behavior?

- How deceptive telecom ads affect customer satisfaction and trust?

- How word of mouth mediates between the independent and dependent variable?

\section{Literature Review}

(Aydin, 2005) Recognized the relationship between customer loyalty and brand image, service quality, trust and switching cost, in the telecommunication industry of turkey as the results revealed that all of these variables had a positive effect on customer loyalty. (Chen, 2011) Completed an investigation in China as they reasoned that brand image direct toward relationship quality, quality coordinates toward relationship esteem, and customer loyalty intercedes through relationship value. The impact of organization image and the brand image was discovered irrelevant. In another study, (Fornell, 2001) explained, when a company satisfies their customers, in a result the company can obtain numerous benefits from the satisfied customer i.e. loyalty, build a positive company image, lessen customer sensitivity and reduce the cost of generating new customers. According to (Anwar, 2011) purchaser trust and brand image affect brand attitude, which can be accomplished through customer desire and particular service quality.

(Alhabeeb, 2007) examined loyalty and customer trust in the viewpoint of significant worth. He proclaimed that the esteem a business is providing for a customer in the sort of its product and service is crucial in the confirmation of trust. The association between the factors connotes that value and perception are emphatically related and trust is decidedly interrelated to loyalty.

(Fayaz, 2015) have explored how deceptive ads affect customer loyalty, attitude, and behavior. The analysis of the study found that deceptive advertising practices happen in mobile phone advertisements which affect customer loyalty. The study also found that when the people experiencing the mobile phone in real and fond some variation in the advertisement, because of this experience, they start thinking that deception occurs in the ads, their faith started shaking towards mobile phones before purchasing. In result to which people start negative word of mouth with other customers whether they may loyal in the past. Similarly, (Hussain, 2015) found that misleading information, stereotyping and unethical advertising is negatively associated with customer purchasing behavior, while the word of mouth is negatively connected with customer satisfaction. Further to it (Jeeva, 2016) have highlighted the impact of misleading advertisement in Coonoor, India and discusses that misleading advertisement has an unfavorable effect on consumer interests and must be coordinated by the legal provisions and institutional structure that adjust misleading advertisement. 
(Maicibi, 2013) have explored that false advertisements generate wrongly use of customer loyalty in the organization. The qualitative research approach is the focus of the study in America. The research observes that organizations generate a cost for the illegal's by falsification and fraud in advertising. (Mohammad Noorizzuddin bin Nooh, 2014) have explored that wrong and inappropriate advertising makes negative belief in the psyche of people particularly adults or children. The qualitative research approach is used in the study in Malaysia and converse that advertising negatively affects children's purchasing decision.

(Liepinyte, 2012) have examined that consumer's buying decision is ending up through misleading practices in advertising at low quality and high prices. (John Cawley, 2013) Conducted research in the USA and found that exposure to deceptive advertising is connected with a lesser possibility that women, and a higher possibility that men, used (OTC) weight loss products. The study suggests that better-educated women are better capable to differentiate fake claims in advertising and is reliable with the allocate effectiveness of education in the creation of health.

(Shaista Kamal, 2015) has explored the relationship between deceptive marketing and consumer behavior in Pakistan. The study shows that mainly all service provider is somehow busy in false claims and exaggerations which is dishonesty and it appears that the advertisers, who do not misinform to their customers, constantly enjoy market shares more than those who exaggerate. It concludes that a higher level of experienced dishonesty was associated with the smaller level of less favorable behaviors, less envying manners and perceived credibility towards the brand, and reduced buying ratio towards the product. As this negative association is against (Mehnaz, 2016) discoveries which demonstrate that false in advertising seen by the customer does not influence loyalty and trust in a negative manner. The examination centers around the qualitative approach with the example size of 232 in Sweden. Further to it (Ali Raza, 2011) has presented that there is a significant and positive association exist among deceptive beauty advertising and the purchasing behavior of university students towards the beauty products, this means that the consumption of beauty products raises with the rise in deception in the beauty products.

(Miluwi, 2011) have explored that advertisement does not essentially verify to be more flourishing in affecting recall of fake claims in India. The result of the study discloses that when both false and true claims are present in a similar advertisement, then true claims are reminded more consistently than false claims. (Waheed Akhter, 2011) explored the key factors which manipulate customer loyalty around the world and particularly in Pakistan. The results indicate that there is a positive association between customer relation, trustworthiness, product image, customer loyalty, and customer satisfaction. It also concludes that long-term sustainable standing and success of a company based on customer loyalty.

(Jiana Daikh, 2015) has demonstrated that there is a significant positive relationship between customer satisfaction and customer loyalty. The study focuses on quantitative research on the sample size of 400 respondents. The study suggests that companies should be doing work hard as because loyalty is a brief issue, therefore today's faithful customers could not be tomorrow's loyal consumers. 


\section{Macrothink}

(Inamullah, 2012) did research in Pakistan that concludes that customer satisfaction has a significant impact on customer loyalty on the other hand customer retention has an insignificant impact on customer loyalty. The study suggests that an organization should well manage their associations with the customers as a determined policy in the mobile telephone market.

(Muhammad Zaman Sarwar, 2012) have highlighted the effect of customer trust on customer retention and customer loyalty. The findings of the study show that customer trust, cause-related marketing, and customer loyalty have a positive association but there is a negative association between customer trust and retention. The implication for the future study is that service operators have need to visibly refine and reframe their procedures concerning religious aspect and generating more easiness to recognized buying ways of the customers to retain them for the long life.

(Hilal Alhulail, 2018) have explored the relationship among word or mouth and customer loyalty to social commerce websites. The study focuses on a quantitative research approach having the sample size of 1000 respondents of social commerce websites consumers in Australia, Factor analyses and SME model is used. The study shows that Word of mouth is the most vital factor which influences customer loyalty.

\subsection{Theoretical Framework}

In view of the literature discussed above, we originate the following research model for the study.

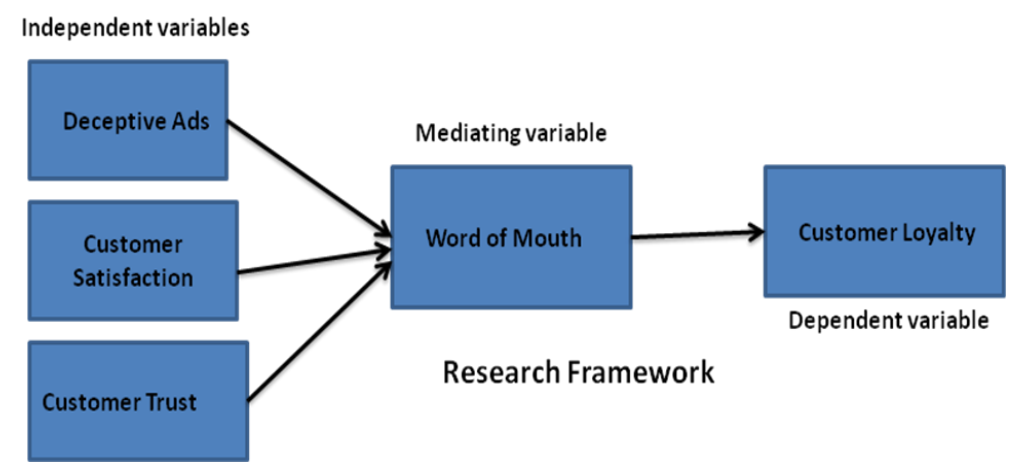

The above model shows that deceptive advertising as an independent variable and its sub variables are customer satisfaction and customer Trust. Customer loyalty as a dependent variable and word of mouth as a mediating variable.

Customer faced with a very huge numbers of advertisements every day in diverse media. This makes the customer unable to judge the false nature of all such messages (Mustansar, 2015). Here they mostly respond on word of mouth. According (Mustansar, 2015) in telecom sector, people share their experiences with other people which some time happen to a strong perception in other's mind that may be transformed in faith towards services. Marketers obviously recognized the value of WOM, particularly with regard to its suggestion for trust and connected outcomes (DeCarlo, 2007). If the customer has a positive experience with a 
brand or service, they might mention it to their family member or a friend. This is because of customer's trust each other's view on what products are worth their money and time and which ones isn't. When the customer comes to know deception occurs in the ads, their believe started shaking towards telecom service before buying, this is because they experienced the services in real and get a difference between advertisement and reality, due to which they started bad word-of-mouth with the people whether they are faithful in the past (Lodhi, 2015).

According to (Hussain, 2015) Misleading information has a negative but insignificant correlation with customer satisfaction. Customer satisfaction is also measured as serious to perform business in today's competitive market and telecom companies are no exemption (Ehigie, 2006) .This retention and possession of customers depend upon the customer's perceived value. As customers' perceived value is the observation of customers about social psychology, quality, compensation, money, and benefits associated with the firm or services. So, if the customer's perceived value is positive then it will create the customer's satisfaction. (Farrell, 2011) a further reminder that perceived unfilled and overstated commitment is negatively related to customer satisfaction.

There are other factors that also affect customer loyalty. One of the significant factor is customer trust. Trust is important to make a strong relationship. As relationship is constructed on trust the most essential thing to consider about trust is that without it, one has no association. This pertains to all human circumstances, not only just the customer service environment, for customers to maintain long business with one and ones businesses, trust has to be earned, and it does not occurs overnight. (Relationship between Customer Satisfaction and Loyalty Business Essay, 2016).

Trust is a promise of the company with their customers to fulfill their expectation as it helps customer loyal to the brand and the company. Without the trust on company customer can't enter in the loyalty set. To build a trust it's essential for the customer to asses and take the information from the product (Ahmed, 2014). The prime issue that demolishes customer trust is when a business breaks their assurances which will the reason customers do not trust the company and even start search for a competitive business that will offer better services (Eideh, 2016). It is very simple to promise brilliance but weakening to deliver can hurt the relationship with the customers. According to (Ibanez, 2006) brand trust is one of the considerable factors which influences brand loyalty. On the other hand (Darke, 2007) has also proposed that deceptive advertising originates consumer's distrust. The reaction of distrust caused by deceptive practices would create a perception of unfairness among consumers that would lessen the chances of repurchases. An angry consumer may resort to other injurious actions such as revealing a bad image of the company or refuse it.

Another factor affecting loyalty is customer satisfaction .In today's marketplace satisfying customer is a business challenge. Every of the company want to attract the customers and they would have the high brand feeling about the product or the services. For this reason customer satisfaction is essential factor that can move the customers towards it. From this point of view if the consumers will satisfy with their definite brand they would make repeat 
purchases and demonstrate commitment (Ahmed, 2014). Now businesses have recognize the importance to understand, predict and meet customer needs. Customer satisfaction is explained as an overall valuation based on the customer's total consumption and purchase experience with the product or service over time. This general satisfaction has a strong constructive outcome on customer loyalty expectations over a wide scope of products and service classifications, including telecom services (Eugene W. Anderson, 2004).

\subsection{Research Hypothesis}

The researcher has generated the following hypothesis for the purpose of final analysis:

H1: Deceptive ads have a positive influence on customer loyalty with the mediation of word of mouth.

$\mathrm{H} 2$ : Customer satisfaction is influenced customer loyalty with the mediation of word of mouth.

H3: Customer satisfaction is influenced customer loyalty with the mediation of word of mouth.

H4: Word-of-mouth has no influence on customer loyalty.

\section{Methodology}

In this segment, the research study converse research design, research model, data collection procedures, statistical techniques, sample size and operational procedures of variables employed in the study.

\subsection{Research Design}

The purpose of this research paper was to examine the impact of deceptive advertisement on customer loyalty in the telecommunication industry of Karachi Pakistan. This paper adopts a descriptive survey design. The targeted audience contains all the individual customers using different telecommunication services in Karachi. The analysis of the study was done on the basis of a quantitative research approach.

\subsection{Research Source}

The main source together the data for this study is primary data which was collected through questionnaires. Similarly, secondary data is also been used to obtain a little help through different books and journals.

\subsection{Questionnaire Design}

The questionnaire consists of two parts the first part includes personal questions about gender, age, education, and income. These questions are intended to get background information about the respondents which would help in descriptive statistics in the analysis part. The questions would get responses on a five-point Likert scale. The points ranged from "1" meaning "strongly agree" to "5" meaning "strongly disagree". The data type used in this 


\section{Macrothink}

research was quantitative approach and all the questions in the questionnaire are closed-ended.

\subsection{Sample Size \& Sampling Techniques}

The sample size of the research paper was of 250. The questionnaire was used to collect responses from different respondents like Students, Teachers, and officers with different age groups. The answers were obtained both electronically and manually. On this bases, the measures of the research are further been carried out.

\subsection{Statistical Techniques}

Exploratory Factor Analysis (EFA) was used to analyze the data with the help of SPSS. Confirmatory Factor Analysis (CFA) and Structural Equation Modeling (SEM) using AMOS, conducted to ensure the model and testing the hypothesis.

\section{Results}

This section represents the empirical findings uncovered from the information and gives data on profiles of the respondents and descriptive statistics for things utilized in the examination.

\subsection{Profile of Respondents}

Table 1, provide statistic data of the respondents which are dispersed after the frequency of each set and their rate share altogether.

Table 1. Demographic information of the respondent

\begin{tabular}{|c|c|c|c|}
\hline Characteristics & Measuring Group & Frequency & Percentage \\
\hline \multirow{3}{*}{ Gender } & Male & 133 & 53.2 \\
\hline & Female & 117 & 46.8 \\
\hline & Total & 250 & 100 \\
\hline \multirow{4}{*}{ Age } & $18-25$ & 162 & 64.8 \\
\hline & $26-30$ & 58 & 23.2 \\
\hline & $31-35$ & 30 & 12 \\
\hline & Total & 250 & 100 \\
\hline \multirow{4}{*}{ Education } & Graduation & 130 & 52 \\
\hline & Masters & 90 & 36 \\
\hline & MPhil & 30 & 12 \\
\hline & Total & 250 & 100 \\
\hline \multirow{6}{*}{ Income } & Below 30,000 & 125 & 50 \\
\hline & 31,000 to 50,000 & 80 & 32 \\
\hline & 51,000 to 70,000 & 31 & 12.4 \\
\hline & 71,000 to 90,000 & 5 & 2 \\
\hline & Above 90,000 & 9 & 3.6 \\
\hline & Total & 250 & 100 \\
\hline
\end{tabular}




\section{Ml Macrothink}

International Journal of Industrial Marketing

ISSN 2162-3066

2019, Vol. 4, No. 1

Table 1 discussed the demographic profile of the respondents as there is a total of 250 respondents out of which $53.2 \%$ are Male and $46.8 \%$ were Females. The dominant part of the respondents i.e.64.8\% are between 18-25 years, respondents between 26-30 years are second biggest at 23.2\% and respondents between 31-35 years had unassuming offer of reactions at $12 \%$ which is a low percentage. While taking a gander at the instruction status it is uncovered that $52 \%$ of respondent are university graduates and another $36 \%$ respondents are at a Masters level and the remainder $12 \%$ of the respondents are MPhil students. The data on monthly income shows that the highest respondents i.e.50\% are reported to be earning below 30,000 as the majority of the respondents are students and $32 \%$ of the respondents monthly income is in between 31,000 to 70,000 , where $2 \%$ of the respondents revealed that their monthly income is in between 71,000 to 90,000 and $3.6 \%$ of the respondents income shows more than above 90,000 .

Table 2. Descriptive analysis of responses for each question

\begin{tabular}{|l|c|c|}
\hline Statement & Mean & Standard Dev. \\
\hline 1. According to you are deception in ads can be easy to identify? & 2.38 & 1.167 \\
\hline 2. Overpromising in ads affect customer believe & 2.50 & 1.162 \\
\hline $\begin{array}{l}\text { 3. The Operator overstates the advantages and attributes of its product and } \\
\text { services }\end{array}$ & 2.50 & 1.162 \\
\hline $\begin{array}{l}\text { 4. The operator utilizes misdirecting strategies to persuade customers to } \\
\text { purchase its product and services }\end{array}$ & 2.98 & 1.002 \\
\hline $\begin{array}{l}\text { 5. When advertisements are found to be misleading, false, or unpleasant, } \\
\text { it is necessary that customer should complain to appropriate bodies. }\end{array}$ & 2.50 & 1.162 \\
\hline $\begin{array}{l}\text { 6.The operator ads are not entirely truthful about its product and services } \\
\text { which may affect customer satisfaction }\end{array}$ & 2.98 & 1.002 \\
\hline $\begin{array}{l}\text { 7. The higher the exposure of false in ads will lead to lower customer } \\
\text { loyalty. }\end{array}$ & 2.59 & .978 \\
\hline $\begin{array}{l}\text { 8. Companies must fulfill their commitment with its customers to earn } \\
\text { loyalty. }\end{array}$ & 2.50 & .995 \\
\hline $\begin{array}{l}\text { 9. Indeed, even my friends and family members suggest me another } \\
\text { operator I will keep on utilizing this one. }\end{array}$ & 2.40 & .986 \\
\hline $\begin{array}{l}\text { 10. Regardless of whether another operator is less expensive, I lean } \\
\text { toward utilizing this one only. }\end{array}$ & 2.22 & .952 \\
\hline 11.Trust has a positive significant influence on customer loyalty & 1.82 & .890 \\
\hline 12. Even I trust on this operator after been deceit. & 1.86 & .890 \\
\hline 13. The operators do care about its customers. & 1.86 & .875 \\
\hline 14. This operators meets customer expectations & 2.05 & 1.044 \\
\hline $\begin{array}{l}\text { 15. Customer satisfaction has often been regards as a major determinant } \\
\text { of customer loyalty. }\end{array}$ & 1.99 & .789 \\
\hline $\begin{array}{l}\text { 16. If any product or services do not makes you satisfy you will be a loyal } \\
\text { customer of that product or a service. }\end{array}$ & 2.08 & .926 \\
\hline
\end{tabular}




\begin{tabular}{|l|c|c|}
\hline $\begin{array}{l}\text { 17. Satisfied customer would say positive things about the product or } \\
\text { service to other people. }\end{array}$ & 2.22 & .907 \\
\hline 18. The operator ads mislead less satisfied customer & 2.23 & .958 \\
\hline 19. Word-of-mouth communication is important for my buying decision. & 2.12 & .801 \\
\hline $\begin{array}{l}\text { 20. Companies must build good relations with its customers to } \\
\text { earn their loyalty, and ensure their commitment }\end{array}$ & 2.50 & .995 \\
\hline $\begin{array}{l}\text { 21. Customer starts bad word-of-mouth with other people after } \\
\text { experiencing the telecommunication ads due to deception occurs in it, } \\
\text { whether they are loyal in past }\end{array}$ & 2.04 & .902 \\
\hline $\begin{array}{l}\text { 22. The Satisfied customer can attract new customer through word-of } \\
\text {-mouth. }\end{array}$ & 1.96 & .803 \\
\hline $\begin{array}{l}\text { 23. The opinion of consumers, who have used the same service before, is } \\
\text { important for me. }\end{array}$ & 2.12 & .849 \\
\hline 24.Word of mouth has an influence on customer loyalty & 2.16 & .912 \\
\hline
\end{tabular}

The above table illustrates the Descriptive statistic analysis which was used in order to know the impact of deceptive advertising on customer loyalty. The descriptive statistic is used to organize, summarize and simplify the data. It enables us to present the data in a more meaningful way and will permit a simpler interpretation of the data. The table shows the mean and standard deviation of the variables that are deceptive ads, customer loyalty, customer satisfaction, trust, and word-of-mouth. Mean is the most commonly used measure of the center of the data and it also referred to as the arithmetic average. The standard deviation shows the variation in data. If the data is close together, the standard deviation will be small. If the data is spread out, the standard deviation will be large. The table shows the highest and lowest mean and standard deviation that is 2.98 at the highest mean value with 1.002 standard deviations and 1.82 at the lowest mean value with 0.890 standard deviations. The results show that the standard deviation is smaller than the mean, as the mean might be representing the data very well.

\subsection{Factor Analysis}

In this section, I will conduct a factor analysis, which is a method for identifying groups of variables. Factor analysis helps to reduce a data set to be a more suitable size. In addition, factor analysis makes it achievable to execute a cluster analysis.

Table 3. Kmo and Bartlett's Test

\begin{tabular}{|c|c|c|}
\hline Kaiser-Meyer-Olkin Measure of Sampling Adequacy. & .727 \\
\hline \multirow{3}{*}{ Bartlett's Test of Sphericity } & Approx. Chi-Square & 1127.217 \\
\cline { 2 - 3 } & Df & 210 \\
\cline { 2 - 3 } & Sig. & .000 \\
\hline
\end{tabular}




\section{Macrothink}

International Journal of Industrial Marketing

ISSN 2162-3066

2019, Vol. 4, No. 1

The KMO and Bartlett's Test measures the strength of the relationship between the variables. From the above table, we can say that the value of KMO test is .727. It means our sample size is sufficient for running factor analysis. From the same table we can also see that Bartlett's Test of Sphericity, the significance value is 0.000 which is less than 0.05 . That means it is significant. So it is confident to say that Factor analysis is suitable for this data.

Table 4. Total variance explained

\begin{tabular}{|c|c|c|c|c|c|c|c|c|c|}
\hline \multirow{2}{*}{} & \multicolumn{4}{|c|}{ Initial Eigenvalues } & \multicolumn{3}{c|}{$\begin{array}{c}\text { Extraction Sums of Squared } \\
\text { Loadings }\end{array}$} & \multicolumn{3}{c|}{ Rotation Sums of Squared } \\
Compoadings
\end{tabular}

Extraction Method: Principal Component Analysis.

Table 5. Rotated component matrix

\begin{tabular}{|c|c|c|c|c|c|}
\hline & & & omponen & & \\
\hline & 1 & 2 & 3 & 4 & 5 \\
\hline LOY1 & & & & .728 & \\
\hline LOY2 & & & & .697 & \\
\hline LOY3 & & & & .422 & \\
\hline LOY4 & & & & .626 & \\
\hline WOM1 & & & & & .611 \\
\hline WOM2 & & & & & .652 \\
\hline WOM3 & & & & & .411 \\
\hline WOM4 & & & & & .433 \\
\hline WOM5 & & & & & .472 \\
\hline TR1 & & & .667 & & \\
\hline TR2 & & & .662 & & \\
\hline TR3 & & & .654 & & \\
\hline TR4 & & & .599 & & \\
\hline CS1 & & .708 & & & \\
\hline $\mathrm{CS} 2$ & & .656 & & & \\
\hline $\mathrm{CS} 3$ & & .624 & & & \\
\hline CS4 & & .599 & & & \\
\hline DADS1 & .880 & & & & \\
\hline
\end{tabular}




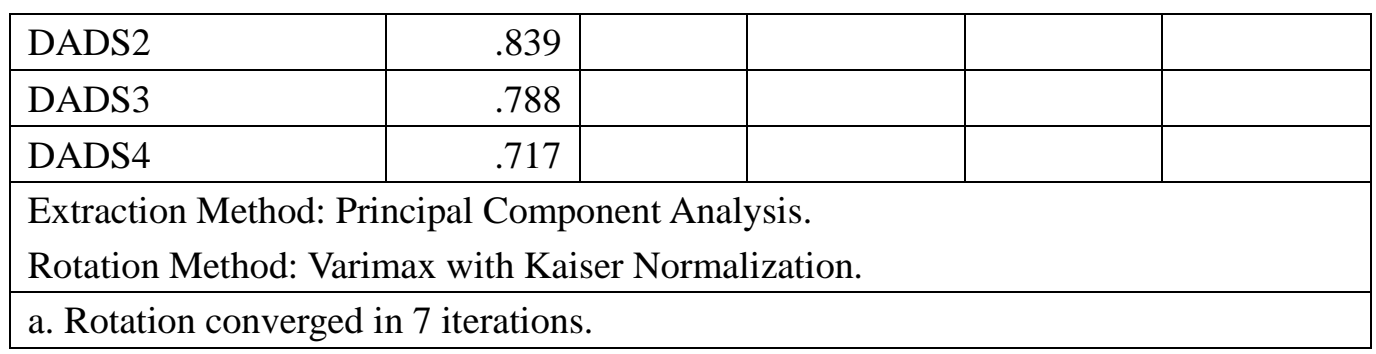

Table 4, indicates the total variance explained at 4 stages .4 factors were extracted out of 21 factors because of their eigenvalues greater than 1 . When 4 factors were extracted, then 50.290 percent of the variance would be explained which is applicable.

Table 5, shows the rotated factor matrix. (Fidell, 2001) confirmed that variable with factor loadings more than 0.45 were selected in this study because loadings equal to 0.45 is measured average, whereas loadings 0.32 is measured less good. After carrying out the Varimax Rotation Method, Factor 1 comprised of 4 items with factor loadings ranging from 0.422 to 0.728 . The items in Factor 1 are LOY1, LOY2, LOY3, and LOY4. Factor 2 comprised of 5 items with factor loadings ranging from 0.411 to 0.652 . The items in Factor 2 are WOM 1, WOM 2, WOM 3, WOM 4 and WOM 5. Factor 3 comprised of 4 items with factor loadings ranging from 0.599 to 0.667 and the items in Factor are TR1, TR2, and TR3 and TR4.

The items in Factor 4 are comprised of 4 items with factor loadings ranging from 0.599 to 0.708. The items in Factor 4 are CS1, CS2, CS3, and CS4. Factor 5 comprised of 4 items with factor loadings ranging from 0.717 to 0.880 and the items in Factor 5 are DADS1, DADS2, DADS3, and DADS4.

\subsection{Construct Development}

An aggregate of 21 items was chosen for the accompanying develops 4 items for Deceptive ads, 4 for Customer Satisfaction, 4 for Trust, 5 for word of mouth and 4 for Customer Loyalty. The items were recognized from leading exploratory factor analysis (EFA) utilizing the principal component method of extraction and Varimax with Kaiser Normalization. Factor loading was between 0.422 to 0.880 which demonstrated high connections between the items and the relating constructs. The following dimensions of positioning have been shortlisted.

\begin{tabular}{|l|l|}
\hline Factor 1 & Customer Loyalty (CL) \\
\hline Factor 2 & Word-of -Mouth (WoM) \\
\hline Factor 3 & Trust (TR) \\
\hline Factor 4 & Customer Satisfaction (CS) \\
\hline Factor 5 & Deceptive Ads (DADs) \\
\hline
\end{tabular}

\subsection{Confirmatory Factor Analysis (CFA)}

After identifying the constructs and their respective explaining variables, confirmatory factor 


\section{Macrothink Institute ${ }^{\mathrm{TM}}$}

analysis has been done to discover the quality of factors in clarifying the related construct. Confirmatory factor analysis (CFA) is a quantitative data analysis method that belongs to the family of (SEM) structural equation modeling techniques. Confirmatory factor analysis is also known as Covariance structure (McDonald, 1978). Confirmatory factor analysis is a theory -testing procedure, where the researcher spells out the number of factors and the pattern of the indicator-factor loadings in advance. Thus the researcher forces the variables to load only on certain factors and observe the fit of that particular model. In CFA, the researchers can indicate that which measured variable is related to which latent variable. It is the tool that is used to authenticate or reject the measurement theory.

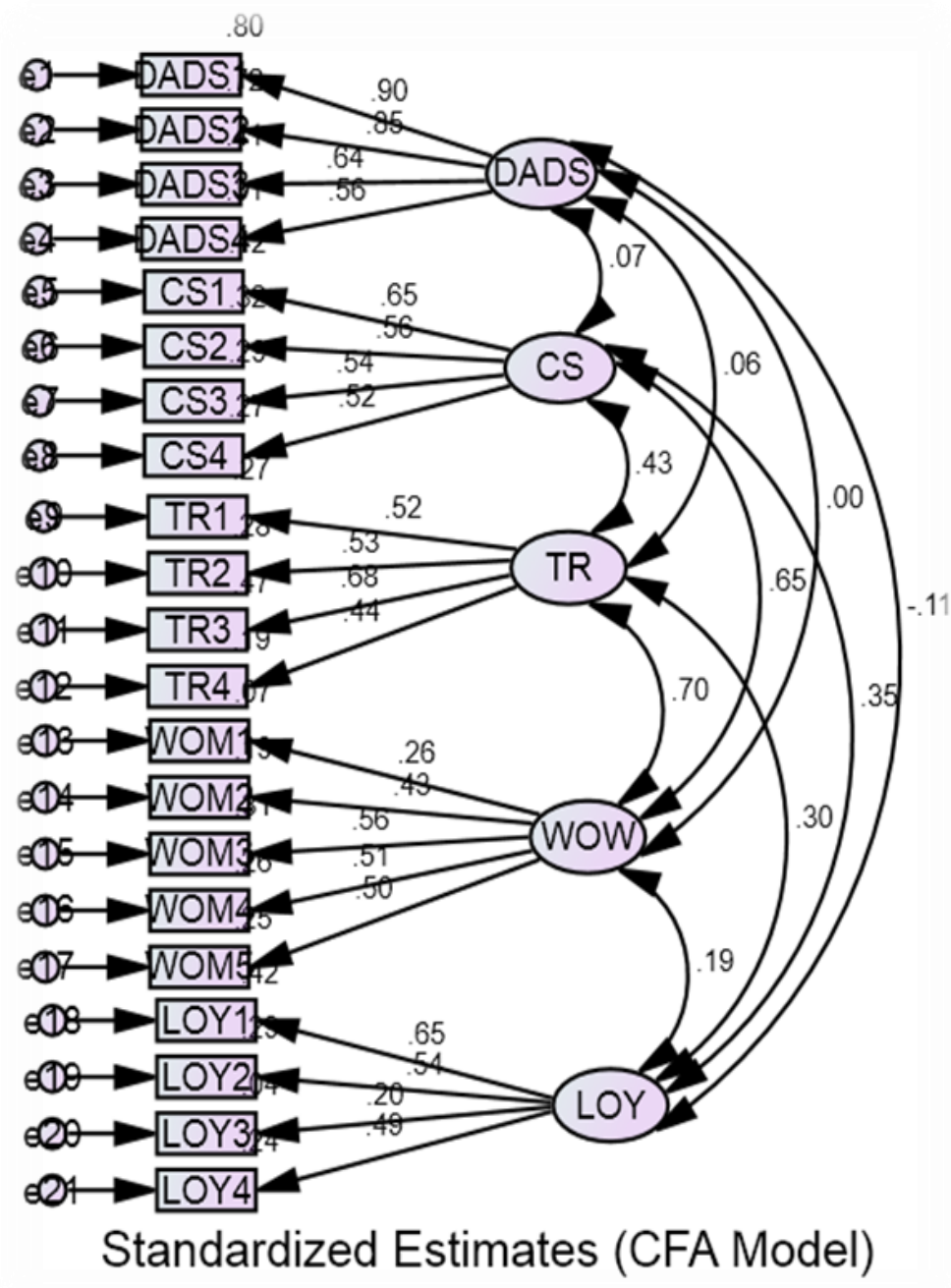

Figure 1. Confirmatory Factor Analysis (CFA) Model with Standardized Estimates

The indices connected to the output factor structure are summarized in table 6 , where the values of the acceptance criteria are also represented.

Figure 1 provides a complete specification of the Confirmatory factor analysis (CFA) model. It is general to display confirmatory factor models as path diagrams in which squares symbolize observed variables and circles signify the latent concepts. Furthermore, single-headed arrows are used to entail a direction of assumed causal influence, and 
double-headed arrows are used to signify covariance among two latent variables (Albright, 2006-2008). As there are five latent constructs which are DADS, CS, TR, WOW and LOY. The DADS1-DADS4, CS1-CS4, TR1-TR4, WOW1-WOM4, and LOY1-LOY4, represents the measured indicator variables. The e1-e21 represents the errors associated with each measured item. The curved arrow among the constructs signifies a correlation relationship between them subsequent to performing CFA develops exhibited great dependability with most factor loading scores. For confirmatory factor analysis, the error of each item is drawn as unobserved variables in round circles and labeled e1 to e4 for (DADS) deceptive ads, e5 to e8 for (CS) customer satisfaction, e9-e12 for (TR) trust, e13 to e17 for (WOM) word-of-mouth and e18-e21 for (LOY) loyalty. During the factor analysis, the factors weight which is lower .25 is excluded but in my analysis all the variables are acceptable. The curved arrow among the latent constructs such as DADS, CS, TR, WOW and LOY signifies a correlation relationship between the entire construct.

\subsection{Model Fit Analysis Summary}

In Model Fit Analysis, the proposed research model will be modified and tested by considering the goodness of fit of the model to the data.

Table 6. Amos output showing model fit

\begin{tabular}{|l|lllll|}
\hline Model & NPAR & $\mathrm{X}^{2}$ & DF & P & $\mathrm{X}^{2} / \mathrm{DF}$ \\
\hline Default model & 52 & 246.647 & 179 & .001 & 1.378 \\
Saturated model & 231 & .000 & 0 & & \\
Independence model & 21 & 1163.830 & 210 & .000 & 5.542 \\
\hline
\end{tabular}

The above table indicates the Value of $\mathrm{X}^{2}$ (chi-square) is 246.647 and is small compared to the value of the Independence model 1163.830. Hence the value is good. As it is also shown in the table that $\mathrm{X}^{2} / \mathrm{DF}$ is $1.378\left(\mathrm{X}^{2}=246 ; \mathrm{DF}=179\right)$ which is less than 5.0, suggesting acceptable model fit.

Table 7. Regression Weights (Group number 1 - Default model)

\begin{tabular}{|c|c|c|c|c|c|c|c|}
\hline & & & Estimate & S.E. & C.R. & $\mathrm{P}$ & Label \\
\hline DADS4 & $<-$ & DADS & 1.000 & & & & \\
\hline DADS3 & $<--$ & DADS & 1.121 & .145 & 7.724 & $* * *$ & \\
\hline DADS2 & $<--$ & DADS & 1.442 & .159 & 9.043 & $* * *$ & \\
\hline DADS 1 & $<--$ & DADS & 1.575 & .173 & 9.115 & $* * *$ & \\
\hline CS4 & $<--$ & CS & 1.000 & & & & \\
\hline CS3 & $<--$ & CS & .980 & .177 & 5.522 & $* * *$ & \\
\hline CS2 & $<--$ & CS & 1.041 & .185 & 5.639 & $* * *$ & \\
\hline CS1 & $<--$ & CS & 1.026 & .171 & 5.990 & *** & \\
\hline
\end{tabular}




\begin{tabular}{|lll|rllll|}
\hline & & & Estimate & S.E. & C.R. & P & Label \\
\hline TR4 & $<---$ & TR & 1.000 & & & & \\
TR3 & $<---$ & TR & 1.315 & .253 & 5.205 & $* * *$ & \\
TR2 & $<---$ & TR & 1.037 & .215 & 4.816 & $* * *$ & \\
TR1 & $<---$ & TR & .940 & .197 & 4.760 & $* * *$ & \\
WOM5 & $<---$ & WOW & 1.000 & & & & \\
WOM4 & $<---$ & WOW & .940 & .183 & 5.147 & $* * *$ & \\
WOM3 & $<---$ & WOW & .974 & .180 & 5.398 & $* * *$ & \\
WOM2 & $<---$ & WOW & .846 & .182 & 4.653 & $* * *$ & \\
WOM1 & $<---$ & WOW & .447 & .143 & 3.123 & .002 & \\
LOY4 & $<---$ & LOY & 1.000 & & & & \\
LOY3 & $<---$ & LOY & .426 & .181 & 2.348 & .019 & \\
LOY2 & $<---$ & LOY & 1.142 & .249 & 4.595 & $* * *$ & \\
LOY1 & $<---$ & LOY & 1.353 & .295 & 4.583 & $* * *$ & \\
\hline
\end{tabular}

Table 7, presents Regression Weight Estimates and it includes estimates, standard error, critical ratio, and P- value. These estimates will tell us whether the construct and their measuring variables have an interrelationship and significant value or not. AS the interrelationship between DADS and DADS1 is positive and significant (standardized estimates $=1.575, \mathrm{CR}=9.115$ and $\mathrm{P}=. * * *)$. AS the interrelationship between CS and CS1 is positive and significant (standardized estimates $=1.026, \mathrm{CR}=5.990$ and $\mathrm{P}=$.***). AS the interrelationship between TR and TR1 is positive and significant (standardized estimates $=.940, \mathrm{CR}=4.760$ and $\mathrm{P}=. * * *)$. AS the interrelationship between WOW and WOM1 is positive and significant (standardized estimates $=.447, \mathrm{CR}=3.123$ and $\mathrm{P}=.002$ ). AS the interrelationship between LOY and LOY1 is positive and significant (standardized estimates = 1.353, $\mathrm{CR}=4.583$ and $\mathrm{P}=* * *)$. The results indicate a very strong and significant interrelationship between the construct and their measuring variables.

Table 8. Correlations (Group number 1 - Default model)

\begin{tabular}{|lll|r|}
\hline & & Estimate \\
\hline CS & $<->$ & TR & .432 \\
TR & $<->$ & WOW & .698 \\
LOY & $<->$ & WOW & .191 \\
CS & $-->$ & WOW & .648 \\
LOY & $-->$ & CS & .350 \\
LOY & $-->$ & DADS & -.112 \\
LOY & $-->$ & TR & .300 \\
DADS & $-->$ & CS & .066 \\
DADS & $-->$ & TR & .064 \\
DADS & $<->$ & WOW & -.003 \\
\hline
\end{tabular}




\section{Macrothink}

Table 8, presents the simple correlation estimates between the variables DADS, CS TR, WOW and. There is a positive correlation between the variables such as CS and TR (Estimate=.432), TR and WOM (Estimate=.698), LOY and WOW (Estimate=.191), CS and WOW (Estimate=.648), LOY and CS(Estimate=.350), LOY and TR (Estimate=.300), DADS and CS(Estimate=.066), DADS and TR(Estimate=.064) but on the other hand there is a negative correlation between LOY and DADS(Estimate=-.112), DADS and WOW $($ Estimate $=-.003)$.

\subsection{Structure Equation Modeling (SEM) Analysis}

It is the combination of factor analysis and multiple regression analysis, it is used to evaluate the structural relationship between latent and measured variables. SEM is also used to show the causal relationship among variables. The relationships are shown in the SEM characterize the hypothesis of the researchers. Structural equation modeling (SEM) refers to a family of statistical methods such as confirmatory factor analysis, structural regression models, path analysis that investigate the relationship between a set of variables. SEM presents several advantages as it allows the researchers to approximate the effects of hypothetical or theoretical constructs, which is commonly called latent variables (Raykov, 2000). In SEM, a number of measured variables can be utilized to estimate the effects of a latent variable. As the analysis of latent variables are both conceptually and statistically appealing and it allows the researcher to recognize a priori models and to evaluate the degree to which the data fits in the specified model. Possibly the most considerable advantage of SEM is that it permits researchers to model the $t$, indirect, direct, and total effects of a system of variables. Consequently, SEM permits researchers to test for and model mediation within the models. A mediator variable is a "middle man," an intervening variable that clarifies the relationship between a dependent variable and a predictor variable (Baron, 1986). An indirect effect refers to the relationship between two variables that is mediated by one or more intervening variables (Raykov, 2000). Structural Equation Model permits the researcher to test a covariance matrix of variables for fit with an earlier hypothesized model. If it fits, it lends confirmation to that model, if it is not fit fine, there may be main missing factors or a diverse model is needed. The SEM model is present in Figure 3 with unstandardized estimates and Figure 4 with standardized estimates. 
4.7 Structure Equation Modeling (SEM) Model

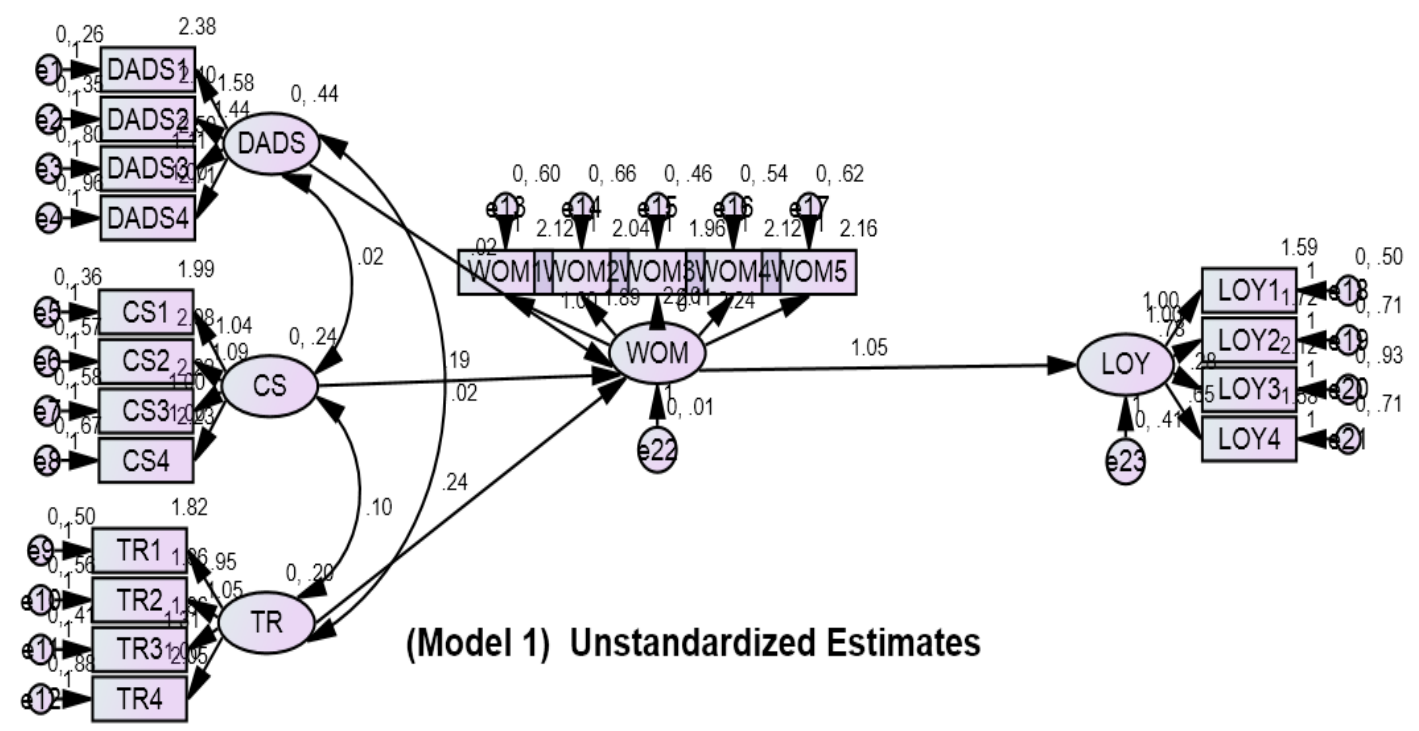

Figure 2. Structure equation model with unstandardized estimates

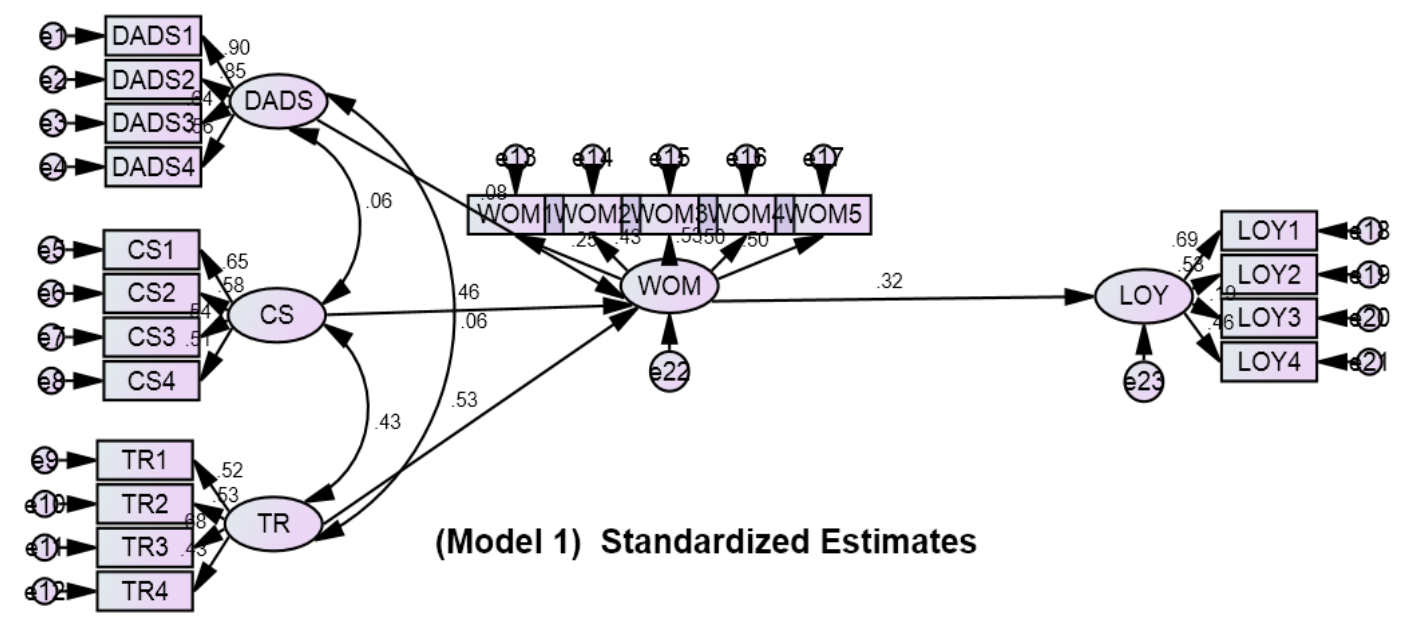

Figure 3. Structure equation model with standardized estimates

\subsection{Model Fit Analysis Summary}

In Model Fit Analysis, the proposed research model will be modified and tested by considering the goodness of fit of the model to the data. 
Table 9. Amos output showing model fit

\begin{tabular}{|l|ccccc|}
\hline Model & NPAR & $\mathrm{X}^{2}$ & $\mathrm{DF}$ & $\mathrm{P}$ & $\mathrm{X}^{2} / \mathrm{DF}$ \\
\hline Default model & 49 & 255.338 & 182 & .000 & 1.403 \\
Saturated model & 231 & .000 & 0 & & \\
Independence model & 21 & 1163.830 & 210 & .000 & 5.542 \\
\hline
\end{tabular}

The above table indicates the Value of $\mathrm{X}^{2}$ (chi-square) is 255.338 and is small compared to the value of the Independence model 1163.830. Hence the value is good. As it is also shown in the table that $\mathrm{X}^{2} / \mathrm{DF}$ is $1.403\left(\mathrm{X}^{2}=255 ; \mathrm{DF}=182\right)$ at $\mathrm{P}=0.00$ which is less than 5.0 , suggesting acceptable model fit.

Table 10. Fit indices of the structural equation model

\begin{tabular}{|l|c|}
\hline Fit Statistics & Values \\
\hline GFI(Goodness of fit index) & .919 \\
\hline AGFI(Adjusted Goodness of Fit Index) & .896 \\
\hline NFI(Normed Fit Index) & .788 \\
\hline RFI(Relative Fit Index) & .751 \\
\hline CFI(Comparative Fit Index) & .929 \\
\hline IFI(Incremental Fit Index) & .931 \\
\hline TLI(Tucker Lewis Index) & .917 \\
\hline RMSEA(Root mean Square Error of Approximation) & .039 \\
\hline RMR(Root Mean Square Residual) & .055 \\
\hline
\end{tabular}

Table 10 presents the fit indices of the structural Equation model. The Goodness of Fit Index (GFI) obtained is 0.919, Adjusted Goodness of Fit Index (AGFI) is 0.896, Normed Fit Index (NFI), Relative Fit index (RFI), Comparative Fit Index (CFI), Tucker-Lewis Index (TLI), and Incremental Fit Index (IFI) are 0.788, 0.751, 0.929, 0.931 and, 0.917.As the RMSEA is 0.039 which is below then the recommended limit of 0.05, and Root Mean Square Residual (RMR) is 0.055 . The Structure Equation Model showed an acceptable overall model fit. Henceforth it is inferred that the proposed research demonstrate fits the information sensibly.

4.11 Standardized Regression Weights (Group number 1 - Default model)

\begin{tabular}{|l|c|}
\hline & Estimate \\
\hline WOM <--- DADS & -.081 \\
WOM <--- CS & .456 \\
WOM <--- TR & .531 \\
LOY <--- WOM & .315 \\
\hline
\end{tabular}




\section{Macrothink}

Table 11, presents the standardized regression estimates which are used to allow the researcher to evaluate directly the relative cause of each independent variable on the dependent variable (Anderson 2006). The results show that all the variables WOM and CS, WOM and TR, LOY and WOM represents a positive standardized estimates $(.456, .531, .315)$. On the other hand, WOM and DADS show negative standardized estimates $(-.081)$.

Table 12. CORRELATIONS (Group number 1 - Default model)

\begin{tabular}{|lll|c|}
\hline & & & Estimate \\
\hline DADS & $<-->$ & CS & .063 \\
TR & $<-->$ & CS & .434 \\
TR & $<-->$ & DADS & .062 \\
\hline
\end{tabular}

Table 12, presents the simple correlation estimates between the variables DADS, CS and TR. As there is a correlation between DADS and CS is 0.63. Moreover, the correlation between TR and CS is 0.434 as well as the correlation between TR and DADS is 0.062 .

Table 13. Regression Weights (Group number 1 - Default model)

\begin{tabular}{|c|c|c|c|c|c|c|c|}
\hline & & & Estimate & S.E. & C.R. & $\mathrm{P}$ & Label \\
\hline WOM & $<--$ & DADS & -.025 & .024 & -1.010 & .313 & \\
\hline WOM & $<--$ & $\mathrm{CS}$ & .188 & .073 & 2.586 & .010 & \\
\hline WOM & $<--$ & TR & .238 & .091 & 2.626 & .009 & \\
\hline LOY & $<--$ & WOM & 1.048 & .444 & 2.357 & .018 & \\
\hline DADS4 & $<--$ & DADS & 1.000 & & & & \\
\hline DADS3 & $<--$ & DADS & 1.114 & .144 & 7.718 & $* * *$ & \\
\hline DADS2 & $<--$ & DADS & 1.437 & .159 & 9.060 & $* * *$ & \\
\hline DADS1 & $<--$ & DADS & 1.578 & .173 & 9.136 & $* * *$ & \\
\hline CS4 & $<--$ & $\mathrm{CS}$ & 1.000 & & & & \\
\hline $\mathrm{CS} 3$ & $<--$ & $\mathrm{CS}$ & 1.002 & .184 & 5.436 & $* * *$ & \\
\hline $\mathrm{CS} 2$ & $<--$ & $\mathrm{CS}$ & 1.088 & .194 & 5.607 & $* * *$ & \\
\hline CS1 & $<--$ & CS & 1.039 & .177 & 5.858 & $* * *$ & \\
\hline TR4 & $<--$ & TR & 1.000 & & & & \\
\hline TR3 & $<--$ & TR & 1.312 & .254 & 5.159 & $* * *$ & \\
\hline TR2 & $<--$ & TR & 1.051 & .219 & 4.804 & $* * *$ & \\
\hline TR1 & $<--$ & TR & .951 & .200 & 4.744 & $* * *$ & \\
\hline WOM1 & $<--$ & WOM & 1.000 & & & & \\
\hline WOM2 & $<--$ & WOM & 1.894 & .631 & 3.000 & .003 & \\
\hline
\end{tabular}




\begin{tabular}{|c|c|c|c|c|c|c|c|}
\hline & & & Estimate & S.E. & C.R. & $\mathrm{P}$ & Label \\
\hline WOM3 & $<--$ & WOM & 2.100 & .665 & 3.157 & .002 & \\
\hline WOM4 & $<--$ & WOM & 2.111 & .675 & 3.125 & .002 & \\
\hline WOM5 & $<--$ & WOM & 2.238 & .718 & 3.117 & .002 & \\
\hline LOY1 & $<--$ & LOY & 1.000 & & & & \\
\hline LOY2 & $<--$ & LOY & .779 & .179 & 4.355 & $* * *$ & \\
\hline LOY3 & $<--$ & LOY & .285 & .124 & 2.293 & .022 & \\
\hline LOY4 & $<-$ & LOY & .645 & .153 & 4.227 & $* * *$ & \\
\hline
\end{tabular}

\section{Discussion of the Result}

Consistent with the projected studies version, there are four hypotheses representing the proposed relationships between the research variables. Structural equation modeling (SEM) using AMOS is employed to test the hypothesis. Table 13, presents Regression Weight Estimates and it includes estimates, standard error, critical ratio, and P-value. These estimates will tell us whether the null hypothesis is rejected or supported. Furthermore for the hypothesis testing the interpretation of the table 9. Is illustrated below:

H0: Deceptive ads have a negative influence on customer loyalty with the mediation of word of mouth.

H2: Deceptive ads have a positive influence on customer loyalty with the mediation of word of mouth.

In the First Hypothesis, deceptive ads have a positive influence on customer loyalty with the mediation of word of mouth. Consequently, the observed output shows that the path between the variables DADS and WOW is negative and insignificant (standardized estimates $=-.025$, and $\mathrm{P}=.313$ ). This negative standardized estimates and insignificant $\mathrm{P}$ value shows that there's no evidence to support the positive effect among the DADS \& WOW on LOY. On the other hand, this negative and insignificant value supports the null hypothesis and indicates that deceptive ads have a negative influence on customer loyalty with the mediation of word of mouth. Hence hypothesis 1 is rejected. As this negative association is against (Mehnaz, 2016) findings that perceived deception has a considerable positive impact on customer loyalty. Further to it, this negative affiliation is related to the findings of (Hussain, 2015) that carrier companies who're occupied in minor levels of deception experience better market proportion. Customers are more loyal to the telecommunication companies that are not involved with better levels of misleading advertisements. Added to it (Fayaz, 2015) signifies that deceptive advertisement as a barrier to customer loyalty and suggests that deceptive advertisement impacts customer loyalty, though they did not nation the energy of the effect and feasible association among the variables.

H0: Customer satisfaction is not influenced customer loyalty with the mediation of word of mouth.

H2: Customer satisfaction is influenced customer loyalty with the mediation of word of mouth. 
In the second Hypothesis, customer satisfaction is influenced customer loyalty with the mediation of word of mouth. Accordingly, the observed output shows that the path between the variables, CS and WOW is positive and strongly significant (standardized estimates $=.188 \mathrm{C}$.R. $=2.586$ and $\mathrm{P}=.010$ ). This positive and strongly substantial value gives proof to reject the null hypothesis and shows that customer satisfaction is causing word of mouth, does it a method that customer satisfaction is influenced customer loyalty with the mediation of word of mouth, as a result, this strong association helps to just accept the Hypothesis 2. This positive association is related to previous studies (Ali Kazemi, 2013) indicates that customer satisfaction influence word of mouth positively. Further to it, ((Bahareh Aliabadi, 2013), (Inamullah, 2012), (Ahmed, 2014) and (Waheed Akhter, 2011)) findings that there is a positive and significant relationship between customer satisfaction and customer loyalty. As a result, it can be said that customer satisfaction is influence customer loyalty in customer's point of views the more the satisfaction, the better the loyalty

H0: Customer trust is not influenced customer loyalty with the mediation of word of mouth.

H3: Customer satisfaction is influenced customer loyalty with the mediation of word of mouth.

In the third Hypothesis, customer trust is influenced customer loyalty with the mediation of word of mouth. Consequently, the observed output shows the path between the variables TR and WOW is positive and strongly significant (standardized estimates $=.238$, C.R. $=2.626$ and $\mathrm{P}=.009)$. Moreover, this positive standardized estimate, the high critical ratio (CR) and strongly significant $\mathrm{P}$ value offers proof to reject the null hypothesis and suggests that customer trust is causing word of mouth, does it means that customer trust is influenced customer loyalty with the mediation of word of mouth. Hence the association is strongly significant and with respect to it, Hypothesis 3 is accepted. This positive and significant association is related to the earlier studies (Mehnaz, 2016), (Bahareh Aliabadi, 2013) and (Ahmed, 2014) findings that there is a positive and strong relationship between customer trust and customer loyalty. As a result, it can be said that trust influence loyalty, in customer point of views; the more the trust, the better the loyalty. It means that customer loyalty increases with the growth in customer trust.

H0: Word-of-mouth has an influence on customer loyalty.

H4: Word-of-mouth has no influence on customer loyalty

In the fourth Hypothesis word of mouth has an influence on customer loyalty. Accordingly, the output shows the path between the variables, WOW and LOY which is positive and strongly significant (standardized estimates $=.1 .048$, C.R. $=2.357$ and $\mathrm{P}=.018$ ). Moreover, this strongly positive standardized estimates, the high critical ratio(CR) and strongly significant $\mathrm{P}$ value gives proof to reject the null hypothesis and suggests that word of mouth is causing loyalty, does it means that word of mouth has a strong influence on customer loyalty. Hence this strong connection helps to accept Hypothesis 4. This positive and significant association is related to previous studies (Ali Kazemi, 2013) findings that customer loyalty is significantly influenced by word of mouth.

The findings suggest that deceptive advertising have a negative effect on customer loyalty with 
the mediation of word of mouth due to the fact, the mediation includes that deception or false perceived by customers effects word of mouth before it impacts customer loyalty. Word of mouth has a significant influence on customer loyalty. The findings also entails that customer satisfaction and customer trust has a positive and significant influence on customer loyalty through word of mouth.

\section{Conclusion}

This study was conducted to spell out the impact of deceptive advertising on customer loyalty. The knowledge gap recognized by way of us in studies gap segment evidence that there are very few studies (Hasan, 2011) (Jahanzeb, 2015) and (Fayaz, 2015) were carried out within the area of deceptive advertising and its effect on customer loyalty under the mediation of word of mouth while none of them point out the effect and relationship between the variables. Deceptive advertising is the use of misleading, false and wrong advertising of a product which may unhelpfully affect customer's moral. Respectively deception or misleading can be confirmed when the customer personally consumes or experience the product or service.

Exploratory Factor Analysis (EFA) on SPSS, Structural Equation Modeling (SEM) and Confirmatory factor analysis (CFA) using AMOS also attended to testing the hypothesis and under the lights of fit guides that the projected model has a good fit.

First of all, our findings revealed that deceptive ads have a negative influence on customer loyalty with the mediation of word of mouth. As this negative association is against (Mehnaz, 2016) findings that perceived deception has a significant positive influence on customer loyalty. Further to it, this negative association is related to the findings of (Hussain, 2015) that service providers who're occupied in minor stages of deception experience better market percentage.

Secondly, the results also demonstrated that customer satisfaction has a positive and significant influence on customer loyalty with the mediation of word of mouth. This positive association is related to previous studies (Ali Kazemi, 2013) indicates that customer satisfaction influence word of mouth positively. Further to it,(Bahareh Aliabadi, 2013; Inamullah, 2012; Ahmed, 2014; and Waheed Akhter, 2011) findings that there is a positive and significant relationship between customer satisfaction and customer loyalty. As a result, it can be said that customer satisfaction is influence customer loyalty in customer's point of views the more the satisfaction, the better the loyalty.

Customer trust is influenced customer loyalty with the mediation of word of mouth. This positive and significant association is related to the earlier studies ((Mehnaz, 2016; Bahareh Aliabadi, 2013; and Ahmed, 2014) findings that there is a positive and strong relationship between customer trust and customer loyalty. As a result, it can be said that trust influence loyalty, in customer point of views; the more the trust, the better the loyalty. It means that customer loyalty increases with the growth in customer trust.

Word of mouth has a strong significant influence on customer loyalty. This positive and significant association is related to previous studies (Ali Kazemi, 2013) findings that customer loyalty is significantly stimulated by means of word of mouth. It means that when a customer 
have a positive experience with a product or service they start positive word of mouth with their friends and family .Similarly When the customer comes to know deception occurs in the ads, their believe started shaking towards telecom service before buying, this is because they experienced the services in real and get a difference between advertisement and reality, due to which they started bad word-of-mouth with the people whether they are faithful in the past (Lodhi, 2015).

The results concluded deceptive ads have a negative influence on customer loyalty with the mediation of word of mouth. Because the mediation entails that deception or false perceived by customer influences word of mouth earlier than it affects customer loyalty. Word of mouth has a significant effect on consumer loyalty. The findings also entail that customer satisfaction and customer trust has a positive and significant influence on customer loyalty through word of mouth.

\section{Implications of the Results}

This study aims to find out the impact of deceptive advertising on customer loyalty and also checked the mediation of word of mouth between deceptive ads, customer satisfaction, customer trust and customer loyalty in telecommunication industry of Pakistan. On the bases of the above findings, this study also has some particle implications. As it is recognized that in order to increase customer loyalty and build a strong relationship with the customer, the telecommunication companies avoid lifting exaggerations and false claims in their ads. Because telling a lie to a customer is wrong and unethical as it will be revealed earlier or later. Based on the study telecom managers are advised to satisfy and better manage their relationships by providing accurate information and quality services to the customers. Further to it, Customer should be alert to obtain all the information regarding the product or service that what service is represented in what price and how many benefits it carries this will makes the customer less lying.

\section{Limitations and Future Research}

This study is carried out in the telecommunication industry only, the future researchers can look into diverse sectors. Moreover, this research can be done further perfectly with more sample size because of the scarcity of time and loads of burden this study was limited to Karachi city.

The people who are willing to choose this topic for further research should conduct a survey of other cities of Pakistan such as Islamabad, Lahore or with the different time frame. This study worked on two variables of customer trust and customer satisfaction. There may be a need for in additional research to discover the other variables i.e., company image, service quality that would further give an explanation for the connection among deceptive advertising and customer loyalty. The significance of customer loyalty and the persistent nature of deceptive ads in our daily existence make this topic attractive and essential.

\section{References}

Ahmed, Z. (2014). Effect of brand trust and customer satisfaction on brand loyalty in 
Bahawalpur. Journal of Sociological Research, 306-326. https://doi.org/10.5296/jsr.v5i1.6568

Albright, J. J. (2006-2008). Confirmatory Factor Analysis using Amos, LISREL, and Mplus. The Trustees of Indiana University.

Alhabeeb, M. J. (2007). On consumer trust and product loyalty. International Journal of Consumer Studies, 609-612. https://doi.org/10.1111/j.1470-6431.2007.00622.x

Ali Kazemi, I. M. (2013). Impact of Brand Identity on Customer Loyalty and Word of Mouth Communications, Considering Mediating Role of Customer Satisfaction and Brand Commitment a case Study: Customers of Mellat Bank in Kermanshah. International Journal of Academic Research in Economics and Management Sciences, 2226-3624. https://doi.org/10.6007/IJAREMS/v2-i4/1

Ali Raza, F. A. (2011). ATTRACTION OF STUDENTS TOWARDS BEAUTY PRODUCTS. Australian Journal of Business and Management Research, 104-108.

Anwar, A. G. (2011). Impact of brand image, trust and affect on consumer brand extension attitude: the mediating role of brand loyalty. International Journal of Economics and Management Sciences, 73-79.

Aydin, S. A. (2005). The analysis of antecedents of customer loyalty in the Turkish mobiletelecommunication market. European Journal of Marketing, 910-92. https://doi.org/10.1108/03090560510601833

Bahareh, A. B. (2013). Design and explain the factors affecting customer loyalty in online banking. International Research Journal of Applied and Basic Sciences, 2782-2791.

Baron, R. M. (1986). The moderator-mediator varivariable distinction in social psychological research: Conceptual,strategic, and statistical considerations. Psychological Bulletin, 1173-1182.

Chen, C. F. (2011). Brand equity, relationship quality, relationship value, and customer loyalty: Evidence from the telecommunications services. Total Quality Management \& Business, 957-974. https://doi.org/10.1080/14783363.2011.593872

Cho, J. Y. (2016). The Regulations of Deceptive Labeling and Advertising in S.Korea:Controversial Issues and Alternatives. International Journal of $u$ - and e-Service, Science and Technology, 91-102.

Darke, P. R. (2007). The Defensive Consumer: Advertising Deception, Defensive Processing, and Distrust. Journal of Marketing Research, 44, 114-127. https://doi.org/10.1509/jmkr.44.1.114

Definition of 'Personal Selling'. (n. d.). Economic Times.

Demaine. (2010). False or misleading advertising.

Ehigie. (2006). 
Eideh, C. (2016). The importance of trust to the customer experience. Digital CX Conversations by Eptica .

Eugene, W., \& Anderson, C. F. (2004). Customer Satisfaction and Shareholder Value. Journal of Marketing, 172-185.

Farooq, M. (2018). Economic Survey 2017-18 Telecom sector revenues. Pakistan today profit .

Farrell, C. J. (2011). Effects of retail employees'behaviours on customers'service evaluation. International Journal of Retail \& Distribution Management, 203-217.

Fayaz, N. (2015). Deceptive Advertising Practices and Customer Loyalty A Case of Mobile Phones in Karachi, Pakistan. European Journal of Business and Management, 83-88.

Fill, C. (1999). Marketing communications: contexts, contents and strategies (2nd ed.). London: Prentice-Hall.

Fornell, C. (2001). A National Customer Satisfaction Barometer: The Swedish Experience. Journal of Marketing, 6-21.

FTC Guides Against Deceptive Pricing. (2012). Federal Trade Government.

Hasan, S. A. (2011). Effects of Deceptive Advertising on Consumer Loyalty in Telecommunication Industry of Pakistan. Information Management and Business Review, 261-264.

Hilal, A. M. D. (2018). The Influence of Word-of-Mouth on Customer Loyalty to Social Commerce Websites. International Conference on Information Resources Management.

Hussain, N. U. (2015). Impact of Unethical Advertising, Misleading Information or Deceptive Advertising on Customer Purchasing Intention withMediating Effect of Word of Mouth: Case of Pakisan. International Journal of Innovation and Economic Development, 49-69.

Ibanez, V. A. (2006). Antecedents of customer loyalty in residential energy markets: Service quality, satisfaction, trust and switching costs. The Service Industries Journal, 633-650. https://doi.org/10.1080/02642060600850717

Inamullah, K. (2012). Impact of Customers Satisfaction And Customers Retention on Customer Loyalty. International Journal of Scientific \& Technology Research, 106-110.

Jahanzeb, S. F. (2015). An empirical analysis of customer loyalty in Pakistan's telecommunication industry. Journal of Database Marketing \& Customer Strategy Management, 5-15.

Jeeva, C. ( 2016). Impact of Misleading Advertisements: Issues and Remedies. Bonfring International Journal of Industrial Engineering and Management Science, 155-157.

Jiana, D. J. A. (2015). The Relationship between Customer Satisfaction and Consumer Loyalty. The Alan Shawn Feinstein Graduate School, 1-15. 
John, C. R. A. (2013). The Effect of Deceptive Advertising on Consumption of the Advertised Good and its Substitutes: The Case of Over-the-Counter Weight Loss Products. Institute of Labor Economics, 1-46.

Kotler, P. (2010). Principles of marketing (13th ed.). global edition.

Lodhi, N. F. (2015). Deceptive Advertising Practices and Customer Loyalty A Case of Mobile Phones in Karachi, Pakistan. International Journal of Scientific and Research Publications, 469-474.

Maicibi, N. A. (2013). Criminal and Unethical Behavioursin Organisations: Misuse of Assets and False or Misleading Advertising. Global Journal of Human Social Science Political Science, 1-9.

Mehnaz, M. S. (2016). The Influence of Deceptive Advertisingon Customer Trust and Loyalty:A Study of Telecom Sector in Pakistan. Umeå School of Business and Economics, $1-5$.

Miluwi, J. O. (2011). Consumerismand Deceptive Advertisement Claim: An Experimental Investigation. International Journal of Information Technology and Knowledge Management, $181-185$

Mittal, T. (2017). The Pakistan telecom story: Will the promise of growth hold? Your story.

Mohammad, N. bin N. et al. (2014). The criteria and challenges of unethical advertising. American Journal of Business,Economics and Management, 88-93.

Muhammad, Z. S. K. S. (2012). The Effect of Customer Trust on Customer Loyalty and Customer Retention: A Moderating Role of Cause Related Marketing. Global Journal of Management and Business Research, 27-39.

Mustansar, N. U. (2015). Impact of Unethical Advertising, Misleading Information or Deceptive Advertising on Customer Purchasing Intention with Mediating Effect of Word of Mouth: Case of Pakistan. International Journal of Innovation and Economic Development, 49-69.

Official Journal of the European Union. (2005). DIRECTIVE 2005/29/EC OF THE EUROPEAN PARLIAMENT AND OF THE COUNCIL.

Outreach, N. (n. d.). Direct Marketing - Everything You Need To Know.

Owais, H. S. (2014). The Pakistani Consumer: Dumb or Dumber? International conference on Marketing, 1-21.

Pahwa, A. (2018). What Is Public Relations? PR Functions, Types, \& Examples. Retrieved from http://Feedough.com

Rajput, 1. I. (2014). Impact of Deceptive Advertising on Customer Behavior and Attitude:Literature Viewpoint. Middle-East Journal of Scientific Research, 244-248.

Ray, L. (2018). What Is the Worst Thing About Deceptive Advertising? Azcentral. 


\section{Macrothink}

Raykov, T. (2000). A first course in structural equation modeling. Mahwah, NJ: Erlbaum.

Relationship Between Customer Satisfaction And Loyalty Business Essay. (2016). ukessays trusted by student since 2003, 8 .

Rizwana, K. (2016). Pakistani Telcos: Who is the King of the Marketing Ring? Phone world.

Skool, M. (n. d.). Deceptive Advertising. Marketing and Strategy Terms.

Sweeney, J. (2008). The effects of brand credibility on customer loyalty. Journal of Retailing and Consumer Services, 179-193.

Taruna, A. S. (September 2016). A study on impact of misleading advertisement on customer preference for soft drinks. International Journal of Multidisciplinary Research and Development, 356-360.

Waheed, A. A. S. (2011). Factors affecting customer loyalty in Pakistan. African Journal of Business Management, 1167-1174.

Waheed, A. A. S. (2011). Factors affecting customer loyalty in Pakistan. African Journal of Business Management, 1167-1174.

Wakeman, O. (n. d.). What Is Considered Illegal Marketing in Other Countries? Retrieved from http://smallbusiness.chron.com

Wilson, J. (2009). Telecom Regulatory \& Policy Environment in Pakistan: Results of the 2008 Tre Survey. LIRNEasia, 1-35.

Yimin, C. N. J. (2015). Misleading Online Content: Recognizing Clickbait as "False News". ResearchGate, 1-6.

\section{Copyright Disclaimer}

Copyright for this article is retained by the author(s), with first publication rights granted to the journal.

This is an open-access article distributed under the terms and conditions of the Creative Commons Attribution license (http://creativecommons.org/licenses/by/3.0/). 